\title{
Comparative Effects of Dominant Forest Tree Species on Soil Characteristics and Microbial Biomass
}

\author{
Yonas Yohannes $^{1 *}$, Olga Shibistova ${ }^{2,3}$ and Georg Guggenberger ${ }^{2}$ \\ ${ }^{1}$ Ethiopian Environment and Forest Research Institute, Addis Ababa, Ethiopia \\ ${ }^{2}$ Institute of Soil Science, Leibniz Universität Hannover, Hannover, Germany \\ ${ }^{3}$ VN Sukachev Institute of Forest, Krasnoyarsk, Russian Federation \\ *yonyoh4@gmail.com, yonyoh4@yahoo.com
}

Keywords: Croton macrostachys, Munessa forest, PLFA, Podocarpus falcatus.

\begin{abstract}
Tree species differ in litter quality and belowground biomass, thereby exerting speciesspecific impact on soil properties and microbial biomass. A study was conducted to find out the comparative effects of Podocarpus falcatus and Croton macrostachys on basic soil characteristics and microbial biomass, in the Munessa forest, Ethiopia. Four experimental plots under the canopies the respected tree species (two from each) were established for sample collection. From these plots, soil samples were collected from a depth $0-10 \mathrm{~cm}$ and $10-25 \mathrm{~cm}$. The results showed that, from the depth $0-10 \mathrm{~cm}$, concentration of organic carbon $(\mathrm{C})$ and nitrogen $(\mathrm{N})$ was larger under $C$. macrostachys and from the depth 10-25 cm these values were greater under P. falcatus. There was significant difference $(p<0.05)$ in cation exchange capacity being larger under $C$. macrostachys. There were no differences in microbial composition between the plots. However, the total phospholipid fatty acids (PLFA) concentration as an entry for microbial biomass determination tended to be significantly larger in soil under Podocarpus plots $\left(382.7 \pm 60.9\right.$ nmol PLFA g ${ }^{-1}$ dry soil) vs. $262.2 \pm 32.8 \mathrm{nmol} \mathrm{PLFA} \mathrm{g}^{-1}$ dry soil (Croton plots). The varying impacts of tree species on soil characteristics and microbial biomass may be partly explained by differences in functional traits related to life-history strategy of the respected species.
\end{abstract}

\section{Introduction}

Montane forests of Africa are recognized as one of the world's most ecologically rich habitats and serve as centres of endemism for plants and animals [1]. In Ethiopia, montane forests are the main constituents of the natural vegetation type [2] of which dry afromontane forest covered the largest part [3]. The dry afromontane forests found in the central and southern Ethiopia have been described as Podocarpus mixed forests. These forests are characterized by a mixture of evergreen and deciduous tree species with predominance of Podocarpus falcatus (Thunb.) Mirb. and Croton macrostachys Del. in upper canopy [4]. While the evergreen gymnosperm P. falcatus is a climax shade tolerant and a late successional tree species, the facultative deciduous angiosperm $C$. macrostachys is a pioneer and light demanding tree [5]. Human activities alter ecosystems and their functions [6]. P. falcatus in Eastern Africa is one of a tree species that is subject to a range of threat due to illegal cutting, grazing and encroachment of forest area. In consequence along with the drastic decline of $P$. falcatus [7], whereas $C$. macrostachys appears to become the first abundant indigenous tree species of Ethiopian highlands [8]. It is known that soils differ dramatically under different types of vegetation and, within forest vegetation, under different species of trees. Hence a shift in relative abundance of different trees in any forest ecosystem may alter a stand-level soil physicochemical and biological properties.

The effect of tree species on soil properties has been of interest for decades [9]. A growing body of evidence has demonstrated that in stand with different dominant tree species, the effect of trees can differ significantly on soil properties and microbial biomass $[10,11,12]$. Individual tree species influence biogeochemical cycling through throughfall and litterfall, and through microbial activities in the soil. Tree species strongly differ in the characteristics of the input of organic residues to the soil in terms of quantity, vertical distribution and substrate quality [13]. On one hand 
this refers to the different litter production and quality $[14,15]$. On the other hand, there is also profound evidence that processes in the rhizosphere are different between different tree species [10]. These peculiarities include the proportion of photosynthates allocated to above-ground and below-ground biomass for different tree species [16], root architecture and fine root distribution [17], and characteristic mycorrhizal associations [18]. Different plant species can selectively stimulate the growth of particular microbial species in the rhizosphere by modifying the nature and rate of organic carbon release into soil [19]. The input pattern of organic substances to soil, may also influence the carbon flow between different functional soil pools. Ashagrie et al. [20, 21] observed a significant decrease in organic carbon and nitrogen storage for soils of the Munessa forest, after clearing of the natural forest and transformation to forest plantations. An experiment that allowed direct comparison of the effects of tree species on a soil within a close location would make statistical comparison more meaningful. Therefore, this study was undertaken to examine the effect of dominant tree species on soil characteristics and soil microbial biomass that are growing in Munessa forest, central parts of Ethiopia.

\section{Materials and Methods}

\section{Study site}

The study was conducted in Munessa-Shashemene Forest found in Oromia Regional State, central Ethiopia, located at $7^{\circ} 13^{\prime} \mathrm{N}$ and $38^{\circ} 37^{\prime} \mathrm{E}$ (Fig. 1). It is a dry montane forest with an estimated area of 23,000 ha of including the adjacent plantation forest and covers an altitudinal range between 2100 and $2700 \mathrm{~m}$. The mean annual rainfall is about $1500 \mathrm{~mm}$, with a minor rainy season occurring from March to May and a major rainy season from July to November. Mean annual air temperature is about $15.3{ }^{\circ} \mathrm{C}$. Vegetation of the natural forest is dominated by the canopy species Podocarpus falcatus (Thunb.) and Croton macrostachys Hochst. Other plant species with relatively less abundance include Prunus africana (Hook. F.) Kalkman, Syzygium guineense (Wild.) DC., Celtis africana Burm. f. and Pouteria adolfi-friederici (Engl.).

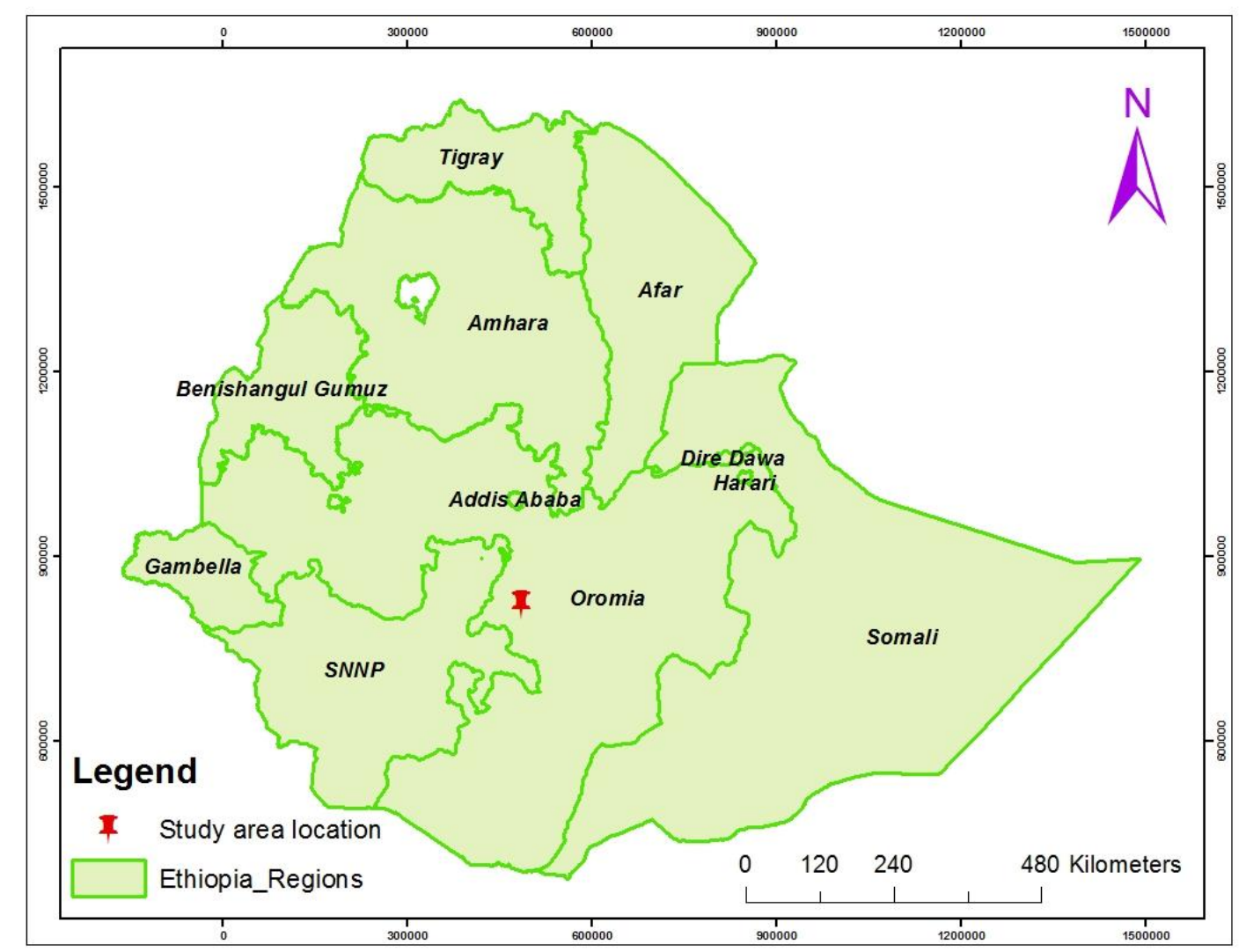

Figure 1. Map of Ethiopia and study area location 


\section{Trees selection and plot establishment}

For the present study, two different functional types of tree species were selected. From angiosperm family Croton macrostachys Hochst. ex Rich (Euphorbiaceae) and from gymnosperm family Podocarpus falcatus (Thunb.) R. Br. ex Mirb. (Podocarpaceae) were selected [5]. Studies on population structure of these tree species in the same forest site, Tesfaye et al. [22] were grouped the trees into different height classes, i.e. $0-2,2-4,4-6,6-8,8-10, \ldots, 28-30$, and $>30 \mathrm{~m}$. From these classes, the third height class (4-6 m) that are available at the distance of c. $100 \mathrm{~m}$ were chosen. Croton macrostachys and $P$. falcatus are the most dominant and ecologically important tree species in the Munessa forest. In order to assess the impact of these tree species on soil microbial biomass and physicochemical properties, two experimental plots under the canopies of the respective tree species were considered. In total, four experimental plots were established for sample collection.

\section{Soil sampling and preparation}

Core soil samples (cylindrical steel core with $4.0 \mathrm{~cm}$ diameter) were obtained separately in triplicate from 0-10 and 10-25 cm depths under the canopy of each experimental tree. Soil samples collected under the canopies of same tree species were bulked. Immediately after collection, the soil samples were sieved with $2 \mathrm{~mm}$ mesh size and all visible fine roots were picked out. After homogenization of each soil sample, aliquots (c. $2 \mathrm{~g}$ ) were taken for organic $\mathrm{C}$ and total organic $\mathrm{N}$ analysis. Air dried samples were finely grinded with a steel ball mill (Mixer Mill, Retsch MM 200) and further dried overnight at $105{ }^{\circ} \mathrm{C}$. Likewise, directly after homogenization of the soil, subsamples of about $10 \mathrm{~g}$ were prepared separately for phospholipids fatty acid (PLFA) and neutral lipid fatty acid (NLFA) analysis. The soil samples were then packed in small glass vials and kept frozen until analyzed.

\section{Laboratory analysis}

Air dried soil samples was used to determine texture by the pipette method [23]. Soil $\mathrm{pH}$ were analyzed potentiometrically in $1 \mathrm{M} \mathrm{KCl}[1: 2.5(\mathrm{~m} / \mathrm{v})]$. Cation exchange capacity (CEC) were determined with the $\mathrm{BaCl}_{2}$ compulsive exchange method [24], Soil organic carbon (SOC) and total nitrogen (TN) contents were analyzed using a Vario EL III elemental analyzer (Elementar Analysensysteme $\mathrm{GmbH}$, Germany). Lipid fatty acid extraction was carried out using frozen soil samples $(1.5 \mathrm{~g})$ extracted overnight with a chloroform-methanol citrate buffer mixture (1:2:08) using a modified method described by Bligh and Dyer [25]. The fatty acid 19:0 (nonadecanoic acid methyl ester) was added to the samples as an internal standard. Lipids were separated into neutral, glyco-, and phospholipids using solid phase extraction with silicic acid column (Bond Elut LRC-Si, Varian Agilent Technologies, Santa Clara, CA). Thereafter, the neutral and phospholipids were subjected to a mild-alkali methanolysis, and the resulting fatty acid methyl esters were separated by gas chromatography using an Agilent 7890A GC-MS (Varian Agilent Technologies, Santa Clara, CA). The fatty acids were quantified by comparison of the peak areas with those of the standard peak. Standard nomenclature was used to refer to the PLFAs according to the designation described in Zelles [26]. Phospholipid fatty acids i15:0, a15:0, i16:0, 18:167c and cy19:0 were used to

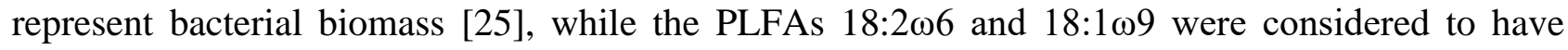

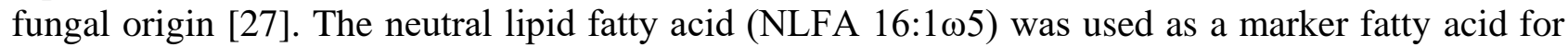
AM fungi [28]. Biomarker phospholipids and neutral fatty acid concentrations (nmol $\mathrm{g}^{-1}$ dry soil) were calculated by comparing peak areas to an analytical standard peak (19:0, Sigma Chemical Co., St. Louis, MO, USA).

\section{Statistical analysis}

The analysis of the collected data for soil physicochemical properties (soil texture, $\mathrm{C}, \mathrm{N}, \mathrm{pH}$, CEC and available P) was expressed as means of three replications for each experimental plot and soil depth. The same statistical analysis was also performed for total PLFAs and 16:165 NLFA concentration. To assess the significance of all data between the $P$. falcatus plots and $C$. macrostachys plots, a t-test was used. Differences were considered significant at the $p<0.05$ level. A t-test or, if normality was not fulfilled after transformation, a Mann-Whitney Rank Sum test were 
used to analyze the difference between the different experimental plots. All graphing and statistical analysis was performed using SigmaPlot version 11 (Systat Software Inc., San Jose, CA, USA).

\section{Results}

\section{Soil physical and chemical properties}

Mean physicochemical properties from the experimental plots under the canopy of the different functional types of trees are given in Table 1. In both experimental plots the soil texture was the same, indicating that the soils developed from the same parent material. The soil texture is predominately a slightly acidic and nutrient rich clay-loam that was evolved from volcanic parent material [29]. The soils were quite homogenous and represented as Mollic Nitisols according to the WRB system [30], this further suggests that the experimental plots are comparable.

There were no statistically significant differences $(p>0.05)$ in soil organic carbon and total $\mathrm{N}$ contents under the broadleaved trees of $C$. macrostachys and the needle leaved $P$. falcatus trees (Table 1). In general, soils of the experimental plots were characterized by high SOC and total nitrogen $(\mathrm{TN})$ concentrations. From the depth $0-10 \mathrm{~cm}$, concentration of SOC and TN was larger under $C$. macrostachys, but from the depth $10-25 \mathrm{~cm}$ these values were greater under $P$. falcatus plots (Table 1). In addition, here was no significant difference in soil $\mathrm{pH}$, available $\mathrm{P}$, as well as base saturation (BS) between the experimental plots $(p>0.05)$, but available $\mathrm{P}$ is larger under $C$. macrostachys and soil $\mathrm{pH}$ tends to be slightly more acidic under $P$. falcatus (Table 1 ). However, there was significant difference in cation exchange capacity (CEC) $(p<0.05)$. As compared to $P$. falcatus, CEC under C. macrostachys is larger and the main ions associated with CEC differences are the exchangeable cations calcium $\left(\mathrm{Ca}^{++}\right)$. Concentrations of SOC and TN decreased with depth and did not differ between the plots (Table 1). Except $\mathrm{pH}$, all physicochemical properties decreased with depth and differ between soil depth. As leaf litter enters the soil surface and root biomass is largest in the topsoil [31], SOC concentration and total $\mathrm{N}$ decreased significantly $(p<0.05)$ from 0 10 to $10-25 \mathrm{~cm}$ soil depth. Concurrently to the decline in SOC the CEC decreased with an increasing soil depth, this shows the impact of soil organic matter on exchangeable nutrients in these forest soils. A similar trend was also observed for available P.

Table 1. Characteristic of the soils under the experimental forest plots

\begin{tabular}{|c|c|c|c|c|c|c|c|c|c|}
\hline $\begin{array}{l}\text { Tree/ } \\
\text { Depth }^{1}\end{array}$ & Sand* & $\begin{array}{l}\text { Silt* } \\
-\mathrm{g} \mathrm{kg}^{-1} \\
\end{array}$ & $\begin{array}{l}\text { Clay* } \\
-\end{array}$ & $\begin{array}{l}C^{\ddagger} \\
-\mathrm{g} \mathrm{l} \\
\end{array}$ & $\begin{array}{c}\mathrm{N}^{\ddagger} \\
\mathrm{g}^{-1}-\end{array}$ & $\mathrm{pH}^{\S}$ & $\begin{array}{c}\mathrm{CEC}^{\mathrm{Il}} \\
\operatorname{mmol}_{(+)} \\
\end{array}$ & $\begin{array}{c}\mathrm{BS}^{2} \\
\% \\
\end{array}$ & $\begin{array}{l}\mathrm{P}_{\text {avail }}{ }^{\dagger \dagger} \\
\mathrm{mg} \mathrm{kg}\end{array}$ \\
\hline \multicolumn{10}{|c|}{ C. macrostachys } \\
\hline $0-10$ & $211 \pm 6$ & $379 \pm 20$ & $410 \pm 26$ & $138^{\mathrm{a}} \pm 2$ & $11.7^{\mathrm{a}} \pm 0$ & $6.7^{\mathrm{a}} \pm 0$. & $732^{\mathrm{a}} \pm 2$ & 100 & $26^{a} \pm 9$ \\
\hline $10-25$ & $219 \pm 2$ & $301 \pm 24$ & $480 \pm 25$ & $64^{\mathrm{b}} \pm 8$ & $5.9^{\mathrm{b}} \pm 0$ & $6.5^{\mathrm{a}} \pm 0$. & $498^{\mathrm{b}} \pm 6$ & 100 & $9.5^{\mathrm{b}} \pm 5$ \\
\hline \multicolumn{10}{|c|}{ P. falcatus } \\
\hline $0-10$ & $180 \pm 3$ & $409 \pm 20$ & $411 \pm 17$ & $116^{\mathrm{a}} \pm 1$ & $11.5^{\mathrm{a}} \pm 0$ & $6.5^{\mathrm{a}} \pm 0$ & $565^{\mathrm{a}} \pm 5$ & 100 & $15^{\mathrm{a}} \pm 3$ \\
\hline $10-25$ & $214 \pm 4$ & $304 \pm 20$ & $482 \pm 24$ & $66^{\mathrm{b}} \pm 13$ & $6.5^{\mathrm{a}} \pm 0$ & $6.2^{\mathrm{a}} \pm 0$ & $376^{\mathrm{d}} \pm 4$ & 100 & $8.6^{\mathrm{b}} \pm 3$ \\
\hline
\end{tabular}

${ }^{1}$ in $\mathrm{cm}$; "measured by the pipette method; total carbon and nitrogen measured by dry combustion (Elementar Vario EL, Hanau, Germany); ${ }^{\S}$ analyzed potentiometrically in $1 \mathrm{M} \mathrm{KCl}[1: 2.5(\mathrm{~m} / \mathrm{v})]$; "cation exchange capacity determined with the $\mathrm{BaCl}_{2}$ compulsive exchange method; ${ }^{2}$ base saturation; †available phosphorus measured after extraction with Bray I solution. Values are mean and standard deviation of three replicated samples. 


\section{Soil microbial biomass}

Relative abundance of individual fatty acids profiles extracted from soils samples under the experimental plots were almost comparable. There are no major differences in mole percentage of individual PLFAs under the experimental plots $(p>0.05)$, which indicates the lack of noticeable effects of soil origin. The normal saturates $16: 0$ and monosaturate 18:1 $117 \mathrm{c}$, methyl branched 10:Me16b and branched chain saturate 115 were the most abundant PLFAs, accounting for 54\% of the total concentration. Monounsaturate 16:1 $107,18: 1 \omega 9$, and Cyclopropyl fatty acid cy 19:0 formed the second most predominant group (24\%). Branched-chain saturates (a15 and i16), monosaturate 16:105 and methyl branched 10:Me16a were $19 \%$ of the total concentration. The least value was

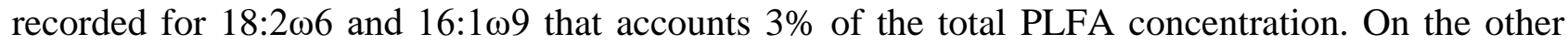
hand, the concentration of total microbial biomass was significantly affected by the different functional types of tree species $(p<0.05)$. In general, PLFA concentration was higher under Podocarpus experimental plots (Fig. 2).

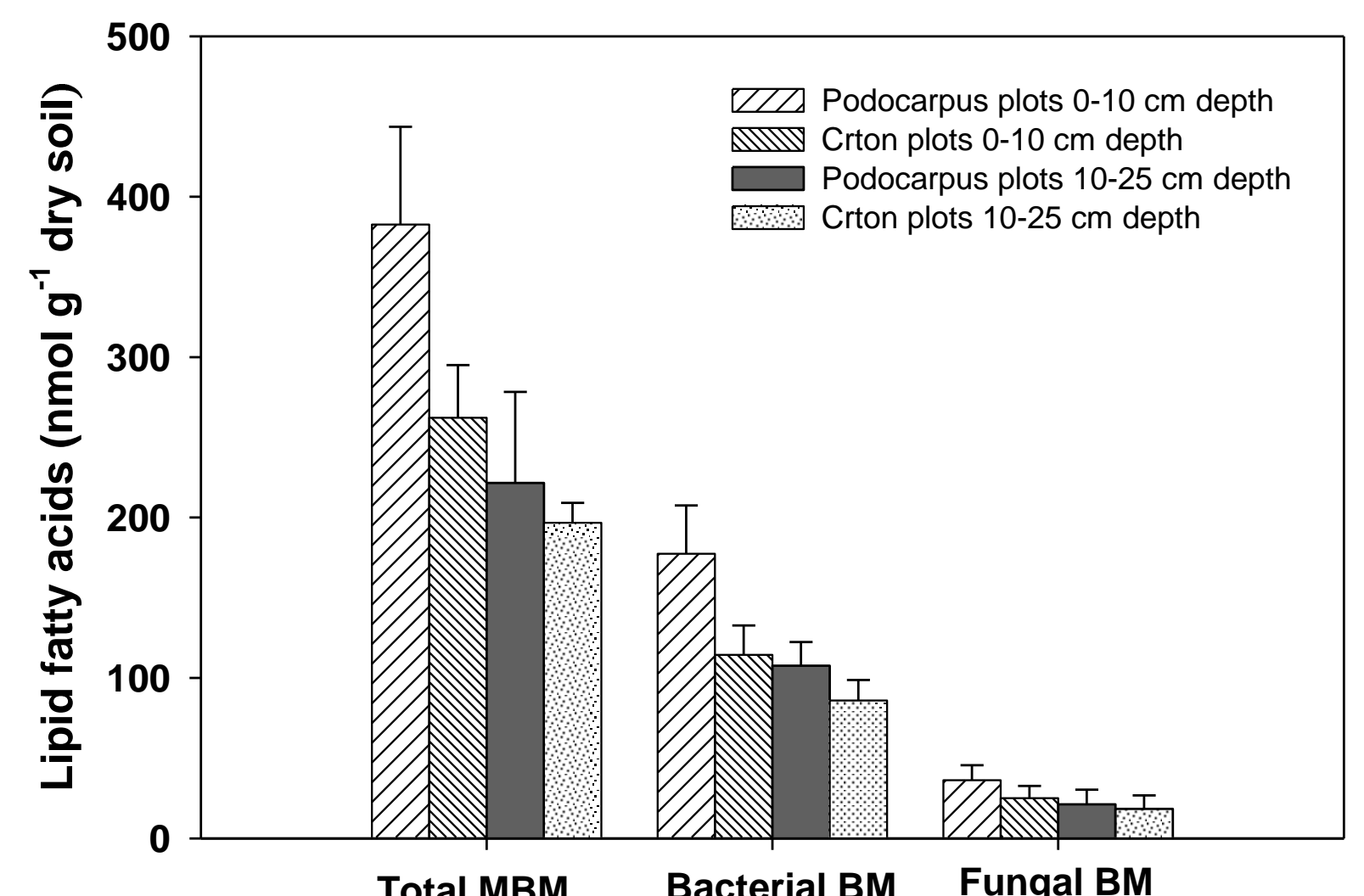

Figure 2. Comparison of total, bacterial and fungal biomass under P. falcatus and C. macrostachys experimental plots from $0-10$ and $10-25 \mathrm{~cm}$ soil depths. Values are mean and standard deviation of six replicated samples. (MBM stands for microbial biomass and BM stands for biomass)

The concentration of all biomarkers decreased with increasing soil depth $(p<0.05)$. The larger concentrations of microbial biomass under Podocarpus experimental plots being attributed to bacteria (nmol bacterial PLFA $\mathrm{g}^{-1}$ dry soil) and fungi (nmol fungal PLFA g ${ }^{-1}$ dry soil). At $0-10 \mathrm{~cm}$

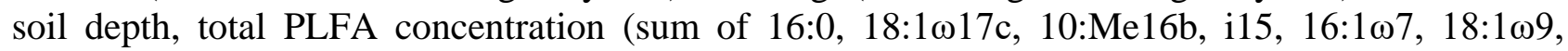

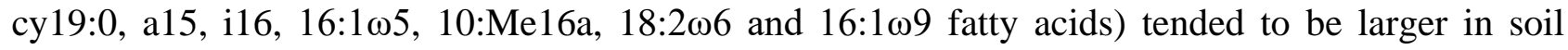
under Podocarpus plots $\left(382.7 \pm 60.9\right.$ nmol PLFA g ${ }^{-1}$ dry soil). Corresponding result under Croton plots was $262.2 \pm 32.8 \mathrm{nmol}$ PLFA $\mathrm{g}^{-1}$ dry soil. From the depth $10-25 \mathrm{~cm}$, total PLFAs concentration under Podocarpus plots and Croton plots was $221.6 \pm 56.7$ and $196.7 \pm 12.5 \mathrm{nmol}$ PLFA g ${ }^{-1}$ dry soil respectively. These values correspond to an increase $46 \%$ in the total microbial biomass in the upper soil (0-10 cm soil depth) and 13\% in the lower soil layer (10-25 cm soil depth) at Podocarpus experimental plots (Fig. 2). On the other hand, the estimation of arbuscular mycorrhizal fungi using signature NLFA16:105 mirrored the same trend as it appears for PLFA 
concentration. However, the gap was reduced at $0-10 \mathrm{~cm}$ and $10-25 \mathrm{~cm}$ and there was no significant difference between the experimental plots $(p>0.05)$ and among the depths $(p>0.05)$. In contrast to Croton experimental plots, the marker NLFA 16:1 15 under $P$. falcatus plots from the depth $0-10 \mathrm{~cm}$ and $10-25 \mathrm{~cm}$ were $18.6 \pm 6.6$ and $12.3 \pm 4.2 \mathrm{nmol} \mathrm{g}^{-1}$ dry soil compared to $16.3 \pm 3.4$ and $11.0 \pm 2.3 \mathrm{nmol} \mathrm{g}^{-1}$ dry soil under Croton experimental plots, respectively.

\section{Discussion}

Previous studies have demonstrated that different tree species influence the soil properties in different ways [see 10, 11, 12]. The production of litter plays a fundamental role in the biogeochemical cycle of organic matter and mineral nutrients. Soil quality is maintained by plant litter which is become a source of nutrients and organic matter after decomposition [32]. The quality and quantity of input by net primary production and its decomposition rate are the two most important factors influencing the amount of SOC storage and other soil quality [33]. Differences in litter quality and nutrient status of the respective tree species could influence the change in soil chemical properties. High concentrations of SOC and total N have been reported previously [20], and are assigned due to high rates of litter input in this productive forest. Furthermore, large contents of reactive minerals (such as $\mathrm{Fe}$ - and Al-(hydroxides) stabilizing SOC by interactions with minerals [29]. In contrast, the soil under $C$. macrostachys appears to be richer in organic carbon and nitrogen. The better soil nutritional status under $C$. macrostachys is likely due to the larger nutrients content in its leaves as compared to P. falcatus (Zech, unpublished). Studies on leaf litter decomposition rate, Abraham [34] reported that $C$. macrostachys is more prone to mass loss and nutrient release. Rapid mass loss was strongly correlated with the soluble labile $\mathrm{C}$ content during the early decomposition phase [35]. This suggested that as compared to $P$. falcatus, $C$. macrostachys litter played a fastest role in regulating the early stage of carbon decomposition and its accumulation on the top, organic layer of soil. On the other hand, fine root biomass and turnover thought to be more important in the accumulation of carbon in forest soils than above-ground litter input [36]. Comparison of the total life fine root (LFR) biomass of the study trees up to the depth interval of $1 \mathrm{~m}$, Abate [31] found out that $P$. falcatus contained significantly higher LFR biomass than $C$. macrostachys trees. As compared to organic layer of soil, the higher concentration of soil organic carbon from the depth $10-25 \mathrm{~cm}$ under the Podocarpus experimental plots potentially attributed by higher concentration of LFR and turnover.

Many factors have been suggested to explain the effects of tree species on microbial biomass in soils [37]. For example, owing to differences in the quantity and quality of substrate inputs via varying litter and root types can be crucial drivers to influence the soil microbial biomass [38, 39]. It is clear from these results that the different functional types of tree species had significant effects on the soil microbial biomass. According to the study made by Abate [31] has shown that, in dry season LFR biomass of $P$. falcatus from the depth $0-10 \mathrm{~cm}$ and $10-35 \mathrm{~cm}$ was found 5170.55 and $2048.75 \mathrm{gm}^{-3}$ vs. 3577.94 and $1659.93 \mathrm{gm}^{-3}$ of $C$. macrostachys, respectively. Therefore, the general increase of total microbial biomass under $P$. falcatus over $C$. macrostachys tree could be attributed to larger fine root biomass of the former tree species. Previous report in the same studied forest has shown that, wild $C$. macrostachys and $P$. falcatus were demonstrated to be arbuscular mycorrhizal [40]. With this regard, larger biomass production requires more nutrient acquisition by the trees, thus leading to larger LFR biomass [31] which led to larger colonization by arbuscular mycorrhiza, as it can be concluded from the larger concentrations of 16:1 $\omega 5$ NLFA under Podocarpus experimental plots. The difference in soil microbial biomass could also emanates from differences in carbon allocation of individual tree species to the below ground component. Fisk and Fahey [41] found out that belowground C supply exerted greater control of forest floor microbial processes than fresh leaf litter inputs. Similarly, fine root mortality transfers considerable amount of organic matter and nutrients in forest soils [42] which may enhance the level of soil microbial biomass under Podocarpus experimental plots. On the other hand, the declining PLFAs and NLFA concentration with soil depth is the result of accompanied decline in organic matter and it is a 
common pattern across many ecosystems [43]. Our results also agreed with those of others [44] who have found that microbial biomass is concentrated at the surface where the concentration of organic matter is also highest.

\section{Conclusion}

In the present study, some of the soil characteristics were unaffected by tree species identity, however the results clearly demonstrate that the dominant tree species has a unique variable effect on the magnitudes of soil chemical and microbial biomass. Furthermore, the soil chemical properties and microbial biomass under the canopies of the respective functional types of the tree species are interrelated. From this, it may be concluded that $P$. falcatus and $C$. macrostachys played their own specific role in sustaining the soil organic matter quality and microbial biomass. This suggested that, ongoing changes in this forest ecosystem, e.g. disturbance as a result of human intervention and changes in precipitation patterns may alter the relative abundance of these tree species, which in turn will likely alter the physicochemical properties of the soil and concentration of microbial biomass. Although, the present study provides a baseline conclusion, long term experiments are needed to examine seasonal trends in a greater detail as well as to better determine factors influencing the soil properties and microbial biomass in this forest ecosystem.

\section{Conflict of Interest}

The authors declare that there is no conflict of interest.

\section{Acknowledgments}

We thank financial support of Deutsche Forschungsgemeinschaft (DFG). We also appreciate the laboratory assistance provided by Institute of Soil Science, Leibniz Universität Hannover.

\section{References}

[1] C.R. Tilbury, Two new chameleons (Sauria: Chamaeleonidae) from isolated Afromontane forests in Sudan and Ethiopia, Bonner Zoologische Beiträge. 47 (1998) 293-299.

[2] F.V. Breitenbach, The indigenous trees of Ethiopia. 2nd ed., Ethiopian Forestry Association, Addis Ababa, Ethiopia, 1963.

[3] D, Teketay, Seed and regeneration ecology in dry Afromontane forests of Ethiopia: I. Seed production - population structures, Tropical Ecology. 46(1) (2005) 29-44.

[4] I. Friies, Forests and Forest Trees of Northeast Tropical Africa. Kew Bulletin, London, UK, 1992.

[5] T.C. Whitmore, Canopy gaps and the two major groups of forest trees. Ecology 70 (1989) 536-538.

[6] D.U. Hooper, et al., Effects of biodiversity on ecosystem functioning: a consensus of current knowledge, Ecological. Monograph. 75 (2005) 3-35.

[7] N. Legesse, Indigenous trees of Ethiopia: Biology, Uses and Propagation Techniques, AAU, Addis Ababa, Ethiopia, 1995.

[8] B. Taye, G. Haase, S. Teshome, Forest genetic resources of Ethiopia: Status and proposed actions, in: S. Edwards et al., (Eds.), Forest Genetic Resources Conservation: Principles, Strategies and Actions, The National forest genetic resources conservation strategy development workshop, IBCR and GTZ; Addis Ababa, Ethiopia, 1999, pp. 39-47. 
[9] D. Binkley, The influence of tree species on forest soils: processes and patterns, in: D.J. Mead, I.S. Cornforth (Eds.), Proceedings of the Trees and Soil Workshop, Lincoln University Press, Canterbury, New Zealand, 1994, pp. 1-33.

[10] J. Bauhus, D. Paré, L. Côté, Effects of tree species, stand age and soil type on soil microbial biomass and its activity in a southern boreal forest, Soil Biology \&. Biochemical. 30 (1998) $1077-1089$.

[11] E. Hackl, Composition of the microbial communities in the mineral soil under different types of natural forest, Soil Biology \& Biochemistry. 37 (2005) $661-671$.

[12] X. Fang, et al., The effects of forest type on soil microbial activity in Changbai Mountain, Northeast China, Annals of Forest Science. 73 (2016) 473-482.

[13] E. Ayres, et al., Tree species traits influence soil physical, chemical, and biological properties in high elevation forests, PLoS ONE. 4 (2009) e5964.

[14] S. Hättenschwiler, Effects of Tree Species Diversity on Litter Quality and Decomposition, in: M. Scherer-Lorenzen, C. Körner, E.D. Schulze (Eds.), Forest Diversity and Function. Ecological Studies (Analysis and Synthesis), Springer, Berlin, Germany, 2005, pp. 149-164.

[15] F. Bernhard-Reversat, Changes in relationships between initial litter quality and $\mathrm{CO}_{2}$ release during early laboratory decomposition of tropical leaf litters, European Journal of Soil \& Biology. 34 (1998) 117-122.

[16] S.J. Grayston, D. Vaughan, D. Jones, Rhizosphere carbon flow in trees, in comparison with annual plants: the importance of root exudation and its impact on microbial activity and nutrient availability, Applied Soil Ecology. 5 (1996) 29-56.

[17] F. Fritzsche et al., Soil-plant hydrology of indigenous and exotic trees in an Ethiopian montane forest, Tree Physiology. 26 (2006) 1043-1054.

[18] R.P. Phillips, T.J. Fahey, Tree Species and Mycorrhizal Associations Influence the Magnitude of Rhizosphere Effects, Ecology. 87(5) (2006) 1302-1313.

[19] P.S. Kourtev, J.G. Ehrenfeld, M. Haggblom, Experimental analysis of the effect of exotic and native plant species on the structure and function of soil microbial communities, Soil Biology \& Biochemistry. 35 (2003) 895-905.

[20] Y. Ashagrie, et al., Changes in soil organic carbon, nitrogen and sulfur stocks due to the conversion of natural forest into tree plantations (Pinus patula and Eucalyptus globulus) in the highlands of Ethiopia, World Resource Review. 15 (2003) 462-482.

[21] Y. Ashagrie, W. Zech, G. Guggenberger, Transformation of a Podocarpus falcatus dominated natural forest into a monoculture Eucalyptus globulus plantation at Munessa, Ethiopia: Soil organic $\mathrm{C}, \mathrm{N}$ and $\mathrm{S}$ dynamics in primary particle and aggregate-size fractions, Agriculture, Ecosystem \& Environment. 106 (2005) 89-98.

[22] G. Tesfaye, et al., Regeneration of seven indigenous tree species in a dry Afromontane forest southern Ethiopia, Flora. 205 (2010) 135-143.

[23] G.W. Gee, J.W. Bauder, Particle-size analysis, in: A. Klute (Ed.), Methods of soil analysis. Part 1. 2nd ed. Agron. Monogr. 9. ASA and SSSA, Madison, WI. 1986, pp. 383-411.

[24] G.P. Gillman, E.A. Sumpter, Modification to the compulsive exchange method for measuring exchange characteristics of soils, Australian Journal of Soil Research. 24 (1986) 61-66.

[25] E.G. Bligh, W.J. Dyer, A rapid method of total lipid extraction and purification, Canadian Journal of Biochemistry \& Physiology. 37 (1959) 911-917.

[26] L. Zelles Fatty acid patterns of phospholipids and lipopolysaccharides in characterization of microbial communities in soil: a review, Biology \& Fertility of Soils. 29 (1999) 111-129. 
[27] L. Zelles, Phospholipid fatty acid profiles in selected members of soil microbial communities, Chemosphere. 35 (1997) 275-294.

[28] P.A. Olsson, A. Johansen, Lipid and fatty acid composition of hyphae and spores of arbuscular mycorrhizal fungi at different growth stages, Mycological Research. 104 (2000) 429-434.

[29] F. Fritzsche, W. Zech, G. Guggenberger, Soils of the Main Ethiopian Rift Valley escarpment: A transect study, Catena. 70 (2007) 209-219.

[30] FAO, ISRIC, ISSS, World Reference Base for Soil Resources, World Soil Resources Report, \#84. FAO, Rome, Italy, 1998.

[31] A. Abate, Biomass and nutrient studies of selected tree species of natural and plantation forests: Implications for a sustainable management of the Munessa-Shashemene Forest, Ethiopia, Ph.D. dissertation, Universität Bayreuth, Germany, 2004.

[32] Z. Koukoura, A.P. Mamolos, K.L. Kalburtji, Decomposition of dominant plant species litter in a semi-arid grassland, Applied Soil Ecology. 23 (2003) 13-23.

[33] M.V. Lutzow et al., Stabilization of organic matter in temperate soils: mechanisms and their relevance under different soil conditions - a review, European Journal of Soil Science. 57 (2006) 426-445.

[34] M. Abraham, Leaf Litter Decomposition and Nutrient Release from Cordia africana Lam. and Croton macrostachyus Del. Tree Species, Journal of Environment and Earth Science. 4(1) (2014) 1-7.

[35] B. Berg, C. McClaugherty, Decomposition as a Process: Some Main Feature, in: Plant Litter: Decomposition, Humus Formation, Carbon Sequestration. 2nd ed.: Springe, Berlin, Germany 2008, ch. 2, pp. 11-31.

[36] R.M.A. Block, K.C.J. Van Rees, J.D. Knight, A review of fine root dynamics in Populus lantations, Agroforestry Systems. 76 (2006) 73-84.

[37] E. Hackl, et al., Microbial nitrogen turnover in soils under different types of natural forest, Forest Ecology \& Management. 188 (2004) 101-112.

[38] W.T. Feng, X.M. Zo., D. Schaefer, Above- and belowground carbon inputs affect seasonal variations of soil microbial biomass in a subtropical monsoon forest of southwest China, Soil Biology \& Biochemistry. 41 (2009) 978-983.

[39] H. Jin, O.J. Sun, J. Liu, Changes in soil microbial biomass and community structure with addition of contrasting types of plant litter in a semiarid grassland ecosystem, Journal of Plant Ecology. 3 (2010) 209-217.

[40] T. Wubet et al., Mycorrhizal status of indigenous trees in dry Afromontane forests of Ethiopia, Forest Ecology and Management. 179 (2003) 387-399.

[41] M.C. Fisk, T.J. Fahey, Microbial biomass and nitrogen cycling responses to fertilization and litter removal in young northern hardwood forests, Biogeochemistry. 53 (2001) 201-223.

[42] A.E. Strand, Irreconcilable Differences: Fine-Root Life Spans and Soil Carbon Persistence, Science. 319 (2008) 456-458.

[43] Y. Feng, et al., Soil microbial communities under conventional-till and no-till continuous cotton systems, Soil Biology \& Biochemistry. 35 (2003) 1693-1703.

[44] P. Chan-Woo, et al., Differences in soil aggregate, microbial biomass carbon concentration, and soil carbon between Pinus rigida and Larix kaempferi plantations in Yangpyeong, central Korea, Forest Science and Technology. 8(1) (2012) 38-46. 